\title{
Serotonin Reuptake Inhibition by Citalopram in Rat Strains Differing for Their Emotionality
}

\author{
Fabrice Pollier, M.S., Sophie Sarre, Ph.D., Sylvie Aguerre, A.S., Guy Ebinger, M.D., \\ Pierre Mormède, Ph.D., Yvette Michotte, Ph.D., and Francis Chaouloff, Ph.D.
}

Acute administration of the selective serotonin (5-HT) reuptake inhibitor (SSRI), citalopram (1-10 $\mathrm{mg} / \mathrm{kg}$, i.p. $1 \mathrm{~h}$ before an elevated plus-maze test), to Spontaneously Hypertensive rats (SHRs), Lewis (LEW) rats, and WistarKyoto (WKY) rats, i.e., rat strains differing for their emotionality, promoted anxiety, and/or hypoactivity, except in WKY rats. In the three strains, such a pretreatment increased central 5-HT levels and/or decreased 5-hydroxyindoleacetic acid levels. Hippocampal, but not midbrain or striatal, $\left[{ }^{3} \mathrm{H}\right]$ citalopram binding at 5-HT transporters was lower in WKY rats than in SHRs. However, neither $\left[{ }^{3} H\right] 5-H T$ reuptake kinetics nor the potencies of citalopram (1-1000 $n M)$ to inhibit $\left[{ }^{3} \mathrm{H}\right] 5-\mathrm{HT}$ reuptake into hippocampal and striatal synaptosomes differed between strains. This was confirmed in vivo by means of microdialysis in the hippocampus of freely moving rats. Thus, although LEW rats displayed a 3-4 fold higher baseline level of extracellular 5-HT in the hippocampus, compared with SHRs and WKY rats, local perfusion with $1 \mu M$ citalopram promoted relative increases in extracellular 5-HT levels over baseline that were similar in all strains. Lastly, acute i.p. administration of $3.3 \mathrm{mg} / \mathrm{kg}$ citalopram ( $1 \mathrm{~h}$ beforehand) decreased to similar extents $\left[{ }^{3} \mathrm{H}\right] 5-\mathrm{HT}$ reuptake into hippocampal synaptosomes from SHRs and WKY rats. This study indicates that genetic differences in the behavioural responses to SSRIs may involve 5-HT transporterindependent mechanisms. [Neuropsychopharmacology 22:64-76, 2000] (c) 1999 American College of Neuropsychopharmacology. Published by Elsevier Science Inc.
KEY WORDS: Serotonin reuptake; Citalopram; Emotionality; Synaptosomes; Microdialysis; Hippocampus

Twin, family, and adoption studies have indicated that affective disorders, either bipolar or unipolar, and anxiety disorders are substantially heritable (Kendler 1996; Merikangas and Swendsen 1997). In keeping with: (i) the compelling and extensive evidence for central 5-hydroxytryptamine (5-HT, serotonin) playing a role in mood

From the Laboratory of NeuroGénétique and Stress (FP, SA, PM, FC), INSERM U471, Bordeaux, France; the Department of Pharmaceutical Chemistry and Drug Analysis (SS, YM), Vrije Universiteit Brussel, Brussels, Belgium; and the Department of Neurology (GE), University Hospital, Brussels, Belgium.

Address correspondence to: Francis Chaouloff, Ph.D., NeuroGénétique et Stress, INSERM U471, Institut F. Magendie, Rue Camille Saint-Saëns, 33077 Bordeaux Cédex, France.

Received March 4, 1999; revised June 28, 1999; accepted July 27, 1999. disorders; and (ii) the key role of the 5-HT transporter, which, by allowing high-affinity reuptake of 5-HT into serotonergic neurones, regulates 5-HT neurotransmission (Amara and Kuhar 1993), the findings that allelic variations in (Collier et al. 1996a; Ogilvie et al. 1996) or nearby (i.e., promoter region) (Lesch et al. 1996; Collier et al. 1996b) the 5-HT transporter gene may have weaken, but significant impacts on affective and anxiety disorders are unsurprising. Moreover, because polymorphism of disease-related genes may also be predictive of drug response (Kleyn and Vesell 1998), it is then not a surprise that the polymorphism within the promoter region of the 5-HT transporter gene leads to a genetic variability of the antidepressant response to the selective serotonin reuptake inhibitor (SSRI) fluvoxamine (Smeraldi et al. 1998).

In rodents, however, no such polymorphisms of the 5-HT transporter gene have been detected; actually, the 
sole information available so far regarding genetic variability in the 5-HT transporter gene and its consequences on emotionality derives from mice bearing a targeted disruption of that gene (Bengel et al. 1998). Thus, 5-HT transporter knocked-out females have been reported to display high anxiety in various novel environments (Wichems et al. 1998).

With regard to the aforementioned findings, this study examined whether rat strains differing with respect to some dimensions of their emotionality (specifically, anxiety and locomotor reactivity) displayed trait variability in: (i) the effectiveness of the 5-HT reuptake system; and/or (ii) the ability of citalopram, the most selective and amongst the most potent 5-HT reuptake inhibitor(s) (Hyttel 1982, 1994) to block that system. To this end, we chose the SHRs, LEW, and WKY inbred strains since SHRs (which derive from WKY rats) (Okamoto and Aoki 1963) display low anxiety but high activity, whereas LEW rats are anxious and normoactive, and WKY rats are anxious and hypoactive (Gentsch et al. 1987; Paré 1989; Ramos et al. 1997). Although SHRs have been selected for their readiness to develop hypertension (Okamoto and Aoki 1963), it is crucial to mention here that differences in emotional reactivity between normotensive WKY rats and hypertensive SHRs (Whitehorn et al. 1983), and normotensive LEW rats and hypertensive SHRs (Ramos et al. 1998), are fully independent from blood pressure differences.

Following the observation of genetic differences in the behavioural responses to citalopram on exposure to an elevated plus-maze test, we then measured: (i) $\left[{ }^{3} \mathrm{H}\right]$ citalopram binding characteristics at 5-HT transporters, synaptosomomal $\left[{ }^{3} \mathrm{H}\right] 5-\mathrm{HT}$ reuptake kinetics, and citalopram-induced decreases in 5-HT metabolism, in midbrain, hippocampus and/or striatum; and (ii) the in vitro and ex vivo inhibitory effect of citalopram on $\left[{ }^{3} \mathrm{H}\right] 5-\mathrm{HT}$ reuptake, and the local effect of citalopram on extracellular 5-HT levels in the hippocampus, as assessed by in vivo microdialysis.

\section{MATERIALS AND METHODS}

\section{Animals}

Male rats from the SHR, LEW, and WKY strains (IFFA CREDO, Les Oncins, France), aged 6-8 weeks on arrival either to Bordeaux or to Brussels, were housed 2-3 per cage under constant temperature $\left(22 \pm 2^{\circ} \mathrm{C}\right)$ and a 12 -h light/dark cycle (lights on at 7 a.m.), with free access to food and water. All rats, including those used for microdialysis experiments, were given at least 2 weeks of recovery before the experiments. All rats were used only once, and all experiments were carried out according to the French and Belgian rules on animal experimentation and welfare.

\section{Elevated Plus-maze Tests}

The elevated plus-maze was made of Perspex ${ }^{R}$, with two opposite open arms $(45 \times 10 \mathrm{~cm})$, and two opposite closed arms of the same size with walls $50-\mathrm{cm}$ high. The arms were connected by a central square $(10 \times 10 \mathrm{~cm})$. In addition, because the floor surface of the maze was smooth, rubber ridges bordering the open arms $(0.5 \mathrm{~cm})$ were added to provide additional grip for the animals. The whole apparatus was elevated $66 \mathrm{~cm}$ above a white floor and exposed to dim illumination (70 lux). The testing procedure was similar to that previously described (Kulikov et al. 1997; Ramos et al. 1997). Thus, between 2 p.m. and 4 p.m., each rat was injected i.p. either with $0.9 \% \mathrm{NaCl}$ or citalopram $(1,3.3$, or $10 \mathrm{mg} / \mathrm{kg}$; H. Lundbeck A/S, Valby, Denmark), returned to its home cage, and placed $1 \mathrm{~h}$ later in the central square of the maze, facing an open arm, the order of testing being rotated by treatment and strain.

The number of entries and the time spent in each arm was then video-monitored for $5 \mathrm{~min}$ (an arm entry being defined as all four feet in the arm). As usually reported, data related to the behaviours in the open arms, which were calculated as their respective ratio over total (open + closed) arm behaviours, are given as percentages. Note that the aforementioned procedure has allowed us to detect the respective anxiolytic and anxiogenic effects of diazepam and pentylenetetrazole in SHRs and LEW rats (WKY rats were not tested at that time) (Ramos et al. 1997).

\section{Analyses of tissue 5-HT and 5-hydroxyindoleacetic (5-HIAA) levels}

Following their 5-min exposure to the elevated plusmaze test (see above), all rats were killed by decapitation, and their midbrain, hippocampi, and striata rapidly dissected out on an ice-cold plate. Tissues were initially stored in dry ice before being stored at $-80^{\circ} \mathrm{C}$ until analysis by HPLC and electrochemical detection, as described previously (Kulikov et al. 1997; Thorré et al. 1997). Tissues were then sonicated in $0.4 \mathrm{~N}$ perchloric acid (containing mercaptoethanol $1 / 500 \mathrm{v} / \mathrm{v}$ ), and centrifuged $(15,000 \mathrm{~g}$ for $10 \mathrm{~min})$. Twenty microliters of supernatant were injected-by means of a Gilson 232 injector (Gilson, Villiers le Bel, France) and a Gilson 401 dilutor -in a reversed phase Spherisorb column $(15 \mathrm{~cm} \times$ $4 \mathrm{~mm}$ i.d., $\mathrm{C}_{8}, 5 \mu \mathrm{M}$ ODS; Touzart et Matignon, Courtaboeuf, France) coupled to a glassy carbon electrode set at $650 \mathrm{mV}(20 \mathrm{nA})$ and a Perkin-Elmer LC 4B (Touzart et Matignon) detector. The mobile phase, a sodium phosphate buffer $(50 \mathrm{mM}, \mathrm{pH} 3.5)$ containing octane sulphonic acid (0.001\%), $0.4 \mathrm{M}$ EDTA, and methanol (15\%), was pumped at a $0.8 \mathrm{ml} / \mathrm{min}$ flow rate. Standard references of 5-HT and 5-HIAA ( $20 \mathrm{pmol} / 20 \mu \mathrm{l})$ and experi- 
mental samples were compared by means of a Shimadzu C-R5A Chromatopore (Touzart et Matignon) integrator.

\section{5-HT Transporter Binding Assays with $\left[{ }^{3} \mathrm{H}\right]$ citalopram}

These assays, which were performed according to D'Amato et al. (1987), have been described previously (Kulikov et al. 1997; Durand et al. 1999). In brief, midbrain, hippocampi, and striata (dissected out from naive rats) were homogenised in 40 volumes of ice-cold Tris- $\mathrm{HCl}$ buffer $(\mathrm{pH}$ 7.4 ) and centrifuged $\left(20,000 \mathrm{~g}\right.$ for $10 \mathrm{~min}$ at $\left.4^{\circ} \mathrm{C}\right)$. The supernatants were discarded and the pellets washed twice by resuspension in 40 volumes of the buffer and centrifuged. The final pellets were then stored at $-80^{\circ} \mathrm{C}$ until binding assays. Then, they were resuspended in a $50 \mathrm{mM}$ Tris- $\mathrm{HCl}$ buffer (pH 7.4) containing $5 \mathrm{mM} \mathrm{KCl}$ and $120 \mathrm{mM} \mathrm{NaCl}$, and transferred to glass tubes.

The reaction was carried out for $1 \mathrm{~h}$ at $25^{\circ} \mathrm{C}$ in the presence of either nine concentrations of $\left[{ }^{3} \mathrm{H}\right]$ citalopram (85 Ci/mmol; Dupont-NEN, Les Ulis, France) ranging from $0.3 \mathrm{nM}$ to $10 \mathrm{nM}$ (midbrain) or two concentrations of $\left[{ }^{3} \mathrm{H}\right]$ citalopram ( $2 \mathrm{nM}$ or $10 \mathrm{nM}$; hippocampi and striata), i.e., concentrations ranging respectively at the $\mathrm{K}_{\mathrm{d}}$ and above the $\mathrm{B}_{\max }$ (data not shown). Non-specific binding (which accounted for $57 \%$ of total binding at the $\mathrm{K}_{\mathrm{d}}$ concentration) was assessed with $10 \mu \mathrm{M}$ paroxetine (SmithKline and Beecham Pharmaceutical, Harlow, England). Midbrain saturation curves were established with duplicates whereas hippocampal and striatal studies were performed with quintuplates. All assays were stopped by the addition of cold buffer followed by a rapid filtration through Whatman GF/B glass fiber filters. The filters were then washed twice with the buffer, and entrapped radioactivity counted by liquid scintillation. Protein concentrations were assessed using bovine serum albumin as standard (Bradford 1976), whereas midbrain $K_{d}$ and $B_{\max }$ values were calculated by means of Prism (version 2.0; GraphPad, San Diego, USA).

\section{$\left[{ }^{3} \mathrm{H}\right] 5-\mathrm{HT}$ Reuptake into Hippocampal and Striatal Synaptosomes}

Fresh hippocampi and/or striata from naive rats and rats injected i.p. with either $0.9 \% \mathrm{NaCl}$ or $3.3 \mathrm{mg} / \mathrm{kg}$ citalopram ( $1 \mathrm{~h}$ beforehand) were homogenised in 20 volumes of ice-cold $0.32 \mathrm{M}$ sucrose, using a glass homogeniser and a Teflon pestle, and centrifuged (1000g at $4^{\circ} \mathrm{C}$ for $10 \mathrm{~min}$ ). The supernatant was removed and centrifuged at $12,000 \mathrm{~g}$ at $4^{\circ} \mathrm{C}$ for $30 \mathrm{~min}$. The resulting $\mathrm{P}_{2}$ pellet was then resuspended in an identical volume of ice-cold $0.32 \mathrm{M}$ sucrose, and used for reuptake studies according to a methodology slightly modified from Thomas et al. (1987).
Sample aliquots of $50 \mu \mathrm{l}$ were preincubated for $5 \mathrm{~min}$ at $37^{\circ} \mathrm{C}$ in the presence of $350 \mu$ l of oxygenated $(5 \% /$ $95 \% \mathrm{CO}_{2} / \mathrm{O}_{2}$ for $30 \mathrm{~min}$ ) Krebs buffer containing 120 $\mathrm{mM} \mathrm{NaCl}, 25 \mathrm{mM} \mathrm{NaHCO} 3,10 \mathrm{mM}$ glucose, $5 \mathrm{mM} \mathrm{KCl}$, $1.2 \mathrm{mM} \mathrm{MgCl}_{2}, 0.05 \mathrm{mM}$ EDTA, $1.3 \mathrm{mM} \mathrm{CaCl}, 1 \mathrm{mM}$ $\mathrm{NaH}_{2} \mathrm{PO}_{4}, 0.1 \mathrm{mM}$ ascorbic acid, and $0.06 \mathrm{mM}$ pargyline (glucose, ascorbic acid, and pargyline were made fresh every day). After preincubation, $50 \mu \mathrm{l}$ of $\left[{ }^{3} \mathrm{H}\right] 5-\mathrm{HT}$ (5 concentrations ranging from 10 to $200 \mathrm{nM} ; 27.5 \mathrm{Ci} /$ mmol, Dupont-NEN) were added, and the tubes left for incubation at $37^{\circ} \mathrm{C}$ for $10 \mathrm{~min}$ under weak agitation. Note that for inhibition studies, $10 \mathrm{nM}\left[{ }^{3} \mathrm{H}\right] 5-\mathrm{HT}$ were added to the buffer that contained (or not: baseline levels) $50 \mu \mathrm{l}$ of citalopram $(0.5-1000 \mathrm{nM})$.

All uptake assays, which were performed in duplicate, were stopped by the addition of cold buffer, followed by a rapid filtration through Whatman GF/C glass fiber filters. The tubes and the filters were then washed with the buffer, and entrapped radioactivity counted by liquid scintillation. Non specific uptake (e.g., which ranged between $12 \%$ and $24 \%$ of total uptake of $10 \mathrm{nM}\left[{ }^{3} \mathrm{H}\right] 5-\mathrm{HT}$ in the three strains) was determined by means of $10 \mu \mathrm{M}$ fluoxetine (Mediat, Milan, Italy). Protein concentrations were assessed using bovine serum albumin as standard (Bradford 1976), whereas respective $K_{m}$ and $V_{\max }$ values on the one hand, and $\mathrm{pIC}_{50}$ values (inhibition studies) on the other hand, were calculated by means of Prism (version 2.0; GraphPad, San Diego, USA).

\section{In Vivo Microdialysis Experiments}

Microdialysis and on-line analysis of extracellular 5-HT were performed as previously described (Thorré et al. 1997). Thus, SHRs, LEW, and WKY rats were anaesthetised i.p. with a mixture of $50 \mathrm{mg} / \mathrm{kg}$ ketamine $/ 5 \mathrm{mg} / \mathrm{kg}$ diazepam and placed on a stereotaxic frame. The skull was exposed, and an intracerebral guide cannula (CMA, Stockholm, Sweden) was implanted just above the ventral hippocampus (coordinates relative to bregma: $\mathrm{L}$ +4.6; A -5.6; V + 4.6) (Paxinos and Watson 1986). Then, a CMA 12 microdialysis probe with a membrane length of $3 \mathrm{~mm}$ was connected to a CMA 100 microdialysis pump, and a modified Ringer's solution $\left(156 \mathrm{mM} \mathrm{Cl}^{-}\right.$, $147 \mathrm{mM} \mathrm{Na}^{+}, 4 \mathrm{mM} \mathrm{K}^{+}$and $1.2 \mathrm{mM} \mathrm{Ca}^{2+}$ ) was pumped through the microdialysis probe at a constant flow rate of $1 \mu \mathrm{l} / \mathrm{min}$. The rats were then allowed to recover from surgery for an approximate $20-\mathrm{h}$ period. Thereafter, dialysates were collected every $20 \mathrm{~min}$ in plastic vials containing $5 \mu \mathrm{l}$ of a filtered antioxidant mixture $(52.6 \mathrm{mM}$ $\mathrm{Na}_{2} \mathrm{~S}_{2} \mathrm{O}_{5}, 100 \mathrm{mM} \mathrm{HCl}, 0.27 \mathrm{mM} \mathrm{Na}_{2}$ EDTA).

Six consecutive samples were first collected under a 2-h perfusion through the microdialysis probe with modified Ringer's solution, after which, $1 \mu \mathrm{M}$ citalopram (in modified Ringer) was perfused for another $2 \mathrm{~h}$ during which six samples were collected. Thereafter, 
Table 1. Effects of Citalopram in SHR, LEW, and WKY Rats Exposed to an Elevated Plus-Maze

\begin{tabular}{lrrrr}
\hline & \multicolumn{4}{c}{ Citalopram $(\mathbf{m g} / \mathbf{k g}, \mathbf{i . p .})$} \\
\cline { 2 - 5 } Behaviour & \multicolumn{1}{c}{$\mathbf{0}$} & $\mathbf{1}$ & $\mathbf{3 . 3}$ & $\mathbf{1 0}$ \\
\hline Open arm entries (\%) & & & \\
SHR & $42.3 \pm 1.9^{a}$ & $35.7 \pm 4.3$ & $36.8 \pm 3.1$ & $30.8 \pm 5.6$ \\
LEW & $9.5 \pm 3.2$ & $19.6 \pm 5.3$ & $14.6 \pm 6.1$ & $15.1 \pm 5.1$ \\
WKY & $14.0 \pm 4.9$ & $8.3 \pm 3.3$ & $9.6 \pm 3.1$ & $26.4 \pm 5.6$ \\
Time in open arms (\%) & & & \\
SHR & $37.4 \pm 4.4^{a}$ & $21.6 \pm 4.6^{c}$ & $20.8 \pm 4.2^{c}$ & $18.4 \pm 7.3^{c}$ \\
LEW & $4.9 \pm 2.6$ & $9.4 \pm 3.3$ & $7.2 \pm 5.3$ & $4.0 \pm 2.3$ \\
WKY & $8.5 \pm 5.0$ & $4.4 \pm 2.1$ & $4.6 \pm 2.1$ & $17.0 \pm 6.9$ \\
Closed arm entries & & & & \\
SHR & $7.5 \pm 0.5^{b}$ & $6.9 \pm 0.4$ & $5.1 \pm 0.6^{d}$ & $4.7 \pm 0.5^{d}$ \\
LEW & $6.4 \pm 0.9$ & $5.9 \pm 0.5$ & $4.8 \pm 0.9$ & $3.5 \pm 0.7^{d}$ \\
WKY & $4.5 \pm 0.6$ & $4.3 \pm 0.7$ & $5.1 \pm 0.7$ & $4.3 \pm 0.7$ \\
Total entries (open + & & & & \\
$\quad$ losed arms) & $13.2 \pm 1.0^{a}$ & $11.3 \pm 1.1$ & $8.4 \pm 1.2^{d}$ & $7.5 \pm 1.1^{d}$ \\
SHR & $7.4 \pm 1.2$ & $7.8 \pm 0.9$ & $6.1 \pm 1.4$ & $4.3 \pm 0.9^{c}$ \\
LEW & $5.4 \pm 0.7$ & $4.9 \pm 0.9$ & $5.8 \pm 0.8$ & $6.0 \pm 0.9$ \\
WKY &
\end{tabular}

The animals were treated with $0.9 \% \mathrm{NaCl}$ or citalopram $1 \mathrm{~h}$ before a 5 -min elevated plus-maze test. Data are the mean \pm SEM values of 12 rats/treatment/strain.

${ }^{a} p<.01,{ }^{b} p<.001$ compared with the WKY strain (note that LEW rats differed also significantly from SHRs, except for closed arm entries). For clarity, inter-strain differences are only shown in $0.9 \%$ NaCl-treated rats.

${ }^{c} p<.05,{ }^{d} p<.01$ compared with $0.9 \% \mathrm{NaCl}$ (citalopram 0 ).

the modified Ringer's solution (i.e., without citalopram) was again locally perfused for another $2 \mathrm{~h}$, thereby allowing the collection of another 6-sample series.

For the analysis of standard and extracellular 5-HT, a validated microbore HPLC system with electrochemical detection was used (Thorré et al. 1997). This system consisted of a Gilson 307 pump (Villiers-le-Bel, France) connected with a UnijetR splitter kit for microbore columns. The column $\left(100 \times 1 \mathrm{~mm}\right.$, i.d., $\mathrm{C}_{8} 5 \mu \mathrm{m}$; BioAnalytical Systems, West Lafayette, IN, USA) was coupled directly to a low-dispersion valve of the water-cooled autosampler (Kontron 465; Kontron Instruments, Milan, Italy). The volume of injection was $10 \mu l$. The microbore analytical column was coupled to the electrochemical cell through a fused silica capillary tubing $(50 \mu \mathrm{m}$, i.d.) to minimise the dead volume of the system. The Decade electrochemical detector with capillary cell design (Antec, Leiden, The Netherlands) was set at $500 \mathrm{mV}$ (range $=$ $10 \mathrm{pA} / \mathrm{V}$ ) against a $\mathrm{Ag} / \mathrm{AgCl}$ reference electrode.

The mobile phase was prepared by adding $30 \mathrm{ml}$ of acetonitrile to $200 \mathrm{ml}$ of a buffer consisting of $100 \mathrm{mM}$ sodium acetate, $20 \mathrm{mM}$ citric acid, $1 \mathrm{mM}$ dibutylamine, $2 \mathrm{mM}$ decanesulfonic acid, and $0.1 \mathrm{mM} \mathrm{Na} \mathrm{m}_{2}$ EDTA $(\mathrm{pH}$ 5.5). The flow rate was set at $0.7 \mathrm{ml} / \mathrm{min}$ yielding a 60 $\mu \mathrm{l} / \mathrm{min}$ flow rate through the microbore column. A dual channel integration computer program was used to integrate the chromatograms (Kontron MT2; Kontron, Milan, Italy). The limit of detection (signal-tonoise ratio $=3$ ) was $0.3 \mathrm{fmol}$.

\section{Statistics}

All values are given as mean \pm SEM. Behaviours in the open arms of the elevated plus-maze, which were expressed as percentages of total (open + closed) arm behaviours (Pellow et al. 1985), did not obey normality rules and were thus analysed by a non-parametric Kruskal-Wallis ANOVA followed by Mann-Whitney tests. All other data were compared by parametric ANOVAs, including with a repeated factor (extracellular 5-HT levels over time) that were followed, if significant, by Tukey's multiple comparison test. For microdialysis data, the average of basal extracellular 5-HT levels (six samples/rat), not corrected for in vivo recovery, was set at $100 \%$; in addition, due to high heterogeneity of variances, all microdialysis data were log-transformed prior to the ANOVA.

\section{RESULTS}

\section{Behavioural Effects of Citalopram (1-10 mg/kg, $1 \mathrm{~h}$ beforehand) in the Elevated Plus-maze}

The percent number of visits to, and time spent on, the open arms varied within rat groups $(\mathrm{H}=53.9, p<$ .0001 , and $\mathrm{H}=54.8, p<.0001$, respectively). Vehicleinjected SHRs displayed more of these behaviours in the open arms, compared with their respective (vehicle-injected) LEW and WKY counterparts. With regard 
$\square$ Vehicle

2um Citalopram $1 \mathrm{mg} / \mathrm{kg}$
Citalopram $3.3 \mathrm{mg} / \mathrm{kg}$

Citalopram $10 \mathrm{mg} / \mathrm{kg}$

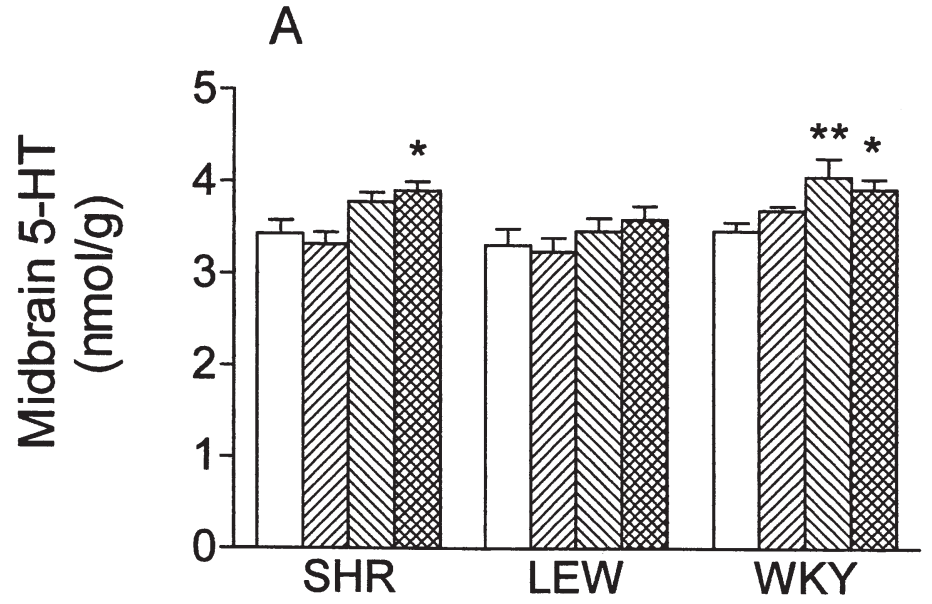

B

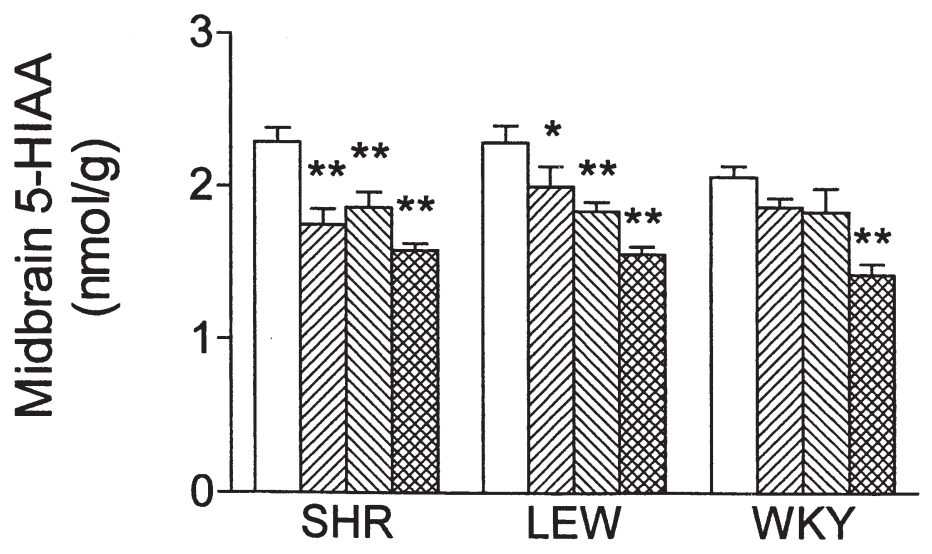

Figure 1. Effects of citalopram (65 min beforehand, i.p.) on midbrain 5-HT (A) and 5-HIAA (B) levels in SHRs, LEW, and WKY rats at the end of a 5-min elevated plus-maze test. Data are the mean \pm SEM of 7-8 rats/treatment/strain. ${ }^{*} p<.05$ and ${ }^{* *} p<.01$ for the effects of citalopram against vehicle in each strain. to citalopram pretreatment, it decreased the percent time spent on open arms in SHRs only, such an effect being yet maximal with the lowest dose of citalopram (Table 1). Of note is the observation that open arm behaviours in WKY rats injected with the highest dose of citalopram tended paradoxically to increase (Table 1).

The number of closed arm entries was affected by both the rat strain and the dose of citalopram administered $(\mathrm{F}(2,132)=5.4, p=.0057$, and $\mathrm{F}(3,132)=5.3, p=$ .0018 , respectively). Lastly, the total number of entries in open and closed arms was found to vary with the rat strain $(\mathrm{F}(2,132)=22.8, p<.0001)$ and the pretreatment $(\mathrm{F}(3,132)=4.3, p=.0061)$, with a significant interaction between both variables $(\mathrm{F}(6,132)=2.4, p=.0314)$ : thus, on the one hand, vehicle-injected SHRs performed more arm entries than their respective LEW and WKY counterparts, whereas on the other hand, citalopram decreased that variable in a dose-dependent manner in SHRs and LEW rats, but not WKY rats (Table 1 ).

\section{Effects of Citalopram (1-10 mg/kg, $65 \mathrm{~min}$ beforehand) on Central 5-HT and 5-HIAA Levels}

Figure 1 and Table 2 depict respectively the effects of citalopram on serotonergic cell bodies (midbrain) and nerve terminals (hippocampus, striatum). In midbrain, 5-HT and 5-HIAA levels were affected by the pretreatment $(\mathrm{F}(3,74)=7.7, p<.0001$, and $\mathrm{F}(3,74)=27.5, p<$ .0001 , respectively), with citalopram increasing significantly 5-HT in SHRs and WKY rats, and decreasing 5-HIAA in all strains, in either a dose-dependent (LEW and WKY rats) or a dose-independent (SHRs) manner (Figure 1).

Neither in hippocampus nor in striatum did citalopram pretreatment affect 5-HT levels, although trends towards increases could be noted in rats injected with the two highest doses. With regard to 5-HT levels, these varied in the hippocampus, but not the striatum, in a strain-dependent manner $(\mathrm{F}(2,74)=10.7, p<.0001$; Ta- 
Table 2. Effects of Citalopram on Central 5-HT and 5HIAA Levels in SHR, LEW, and WKY Rats

\begin{tabular}{|c|c|c|c|c|}
\hline & \multicolumn{4}{|c|}{ Citalopram (mg/kg, i.p.) } \\
\hline & 0 & 1 & 3.3 & 10 \\
\hline \multicolumn{5}{|c|}{ Hippocampal 5-HT (nmol/g) } \\
\hline SHR & $1.55 \pm 0.08$ & $1.71 \pm 0.06$ & $1.76 \pm 0.05$ & $1.66 \pm 0.07$ \\
\hline LEW & $1.56 \pm 0.05$ & $1.52 \pm 0.05$ & $1.48 \pm 0.03$ & $1.56 \pm 0.06$ \\
\hline WKY & $1.50 \pm 0.05$ & $1.48 \pm 0.07$ & $1.47 \pm 0.08$ & $1.48 \pm 0.05$ \\
\hline \multicolumn{5}{|c|}{ Hippocampal 5-HIAA (nmol/g) } \\
\hline SHR & $1.30 \pm 0.03^{a}$ & $1.05 \pm 0.10^{c}$ & $1.11 \pm 0.09^{c}$ & $0.96 \pm 0.08^{d}$ \\
\hline LEW & $1.23 \pm 0.05$ & $1.14 \pm 0.08$ & $1.09 \pm 0.07$ & $1.02 \pm 0.07^{c}$ \\
\hline WKY & $1.07 \pm 0.06$ & $0.98 \pm 0.02$ & $0.86 \pm 0.05^{c}$ & $0.82 \pm 0.05^{d}$ \\
\hline \multicolumn{5}{|c|}{ Striatal 5-HT (nmol/g) } \\
\hline SHR & $2.06 \pm 0.22$ & $2.18 \pm 0.13$ & $2.32 \pm 0.20$ & $2.22 \pm 0.11$ \\
\hline LEW & $2.26 \pm 0.30$ & $2.25 \pm 0.13$ & $2.25 \pm 0.11$ & $2.57 \pm 0.07$ \\
\hline WKY & $2.17 \pm 0.13$ & $2.39 \pm 0.09$ & $2.41 \pm 0.16$ & $2.71 \pm 0.26$ \\
\hline \multicolumn{5}{|c|}{ Striatal 5-HIAA (nmol/g) } \\
\hline SHR & $1.84 \pm 0.09^{b}$ & $1.54 \pm 0.09^{c}$ & $1.66 \pm 0.10$ & $1.43 \pm 0.10^{d}$ \\
\hline LEW & $1.86 \pm 0.08^{a}$ & $1.89 \pm 0.09$ & $1.67 \pm 0.08$ & $1.57 \pm 0.07^{c}$ \\
\hline WKY & $2.22 \pm 0.12$ & $1.66 \pm 0.08^{d}$ & $1.39 \pm 0.12^{d}$ & $1.43 \pm 0.15^{d}$ \\
\hline
\end{tabular}

The animals were treated with $0.9 \% \mathrm{NaCl}$ or citalopram $1 \mathrm{~h}$ before a 5 -min elevated plus-maze test, and sacrificed thereafter. Data are the mean \pm SEM values of $6-8$ rats/treatment/strain.

${ }^{a} p<.05,{ }^{b} p<.0 .1$ compared with the WKY strain (for clarity, interstrain differences are only shown in $0.9 \% \mathrm{NaCl}$-treated rats).

${ }^{c} p<.05,{ }^{d} p<.01$ compared with $0.9 \% \mathrm{NaCl}$ (citalopram 0 ).

ble 2). As concerns 5-HIAA, both the rat strain $(\mathrm{F}(2,74)=$ $9.8, p=.0002)$ and the pretreatment $(\mathrm{F}(3,74)=8.1, p<$ .0001) affected hippocampal 5-HIAA levels, whereas in striatum, only did the pretreatment $(\mathrm{F}(3,71)=14.1, p<$ $.0001)$ and the strain $\times$ pretreatment interaction $(\mathrm{F}(6,71)=$ $3.1, p=.0102)$, show significant influences.

In confirmation, post hoc tests revealed that vehicleinjected WKY rats displayed lower hippocampal 5-HIAA levels than their SHR counterparts, but higher striatal 5-HIAA levels than their SHR and LEW counterparts (Table 2). In addition, citalopram-induced reduction in 5-HIAA levels were almost dose-dependent in each brain region, with the hippocampus of SHRs and the striatum of WKY rats being the most sensitive regions (Table 2).

\section{$\left[{ }^{3} \mathrm{H}\right]$ citalopram Binding at Midbrain, Hippocampal, and Striatal 5-HT Transporters}

In midbrain, the characteristics of $\left[{ }^{3} \mathrm{H}\right]$ citalopram $(0.3-$ $10 \mathrm{nM}$ ) specific binding to 5-HT transporters did not differ between strains, whether $\mathrm{B}_{\max }$ values $(542 \pm 41$, $639 \pm 68$, and $536 \pm 36 \mathrm{fmol} / \mathrm{mg}$ protein in SHRs, LEW, and WKY rats, respectively) or $K_{d}$ values ( $2.58 \pm 0.27$, $3 \pm 0.42$, and $2.44 \pm 0.39 \mathrm{nM}$ in SHRs, LEW, and WKY rats, respectively) were considered (data not shown). At serotonergic nerve terminals, it was found that the amount of $\left[{ }^{3} \mathrm{H}\right]$ citalopram specifically bound by $5-\mathrm{HT}$ transporters was strain-dependent in the hippocampus
$(\mathrm{F}(2,40)=4.9, p=.0123)$, but not in the striatum (Table 3). Actually, WKY rats displayed lower hippocampal $\left[{ }^{3} \mathrm{H}\right]$ citalopram binding, compared with SHRs, an effect that reached significance when $10 \mathrm{nM}$, but not $2 \mathrm{nM}$ $\left[{ }^{3} \mathrm{H}\right]$ citalopram were used (Table 3).

\section{$\left[{ }^{3} \mathrm{H}\right] 5-\mathrm{HT}$ Reuptake (10-200 nM) into Hippocampal and Striatal Synaptosomes}

As shown in Table 3, neither the $V_{\max }$ nor the $K_{m}$ values related to hippocampal $\left[{ }^{3} \mathrm{H}\right] 5-\mathrm{HT}$ reuptake differed between strains, an observation that held true for striatal $\left[{ }^{3} \mathrm{H}\right] 5-\mathrm{HT}$ reuptake characteristics, including for $\mathrm{V}_{\max }$ values $(\mathrm{F}(2,11)=3.1)$.

\section{In Vitro Inhibitory Effects of Citalopram (1-1000 nM) on Hippocampal and Striatal $\left[{ }^{3} \mathrm{H}\right] 5-\mathrm{HT}$ Reuptake}

Citalopram caused a concentration-dependent, but strain-independent (see below), inhibition of $10 \mathrm{nM}$ $\left[{ }^{3} \mathrm{H}\right] 5-\mathrm{HT}$ reuptake into hippocampal and striatal synaptosomes; however, it was observed that the maximal inhibition of $\left[{ }^{3} \mathrm{H}\right] 5-\mathrm{HT}$ reuptake by citalopram ranged between $84-88 \%$ in hippocampus and $75-77 \%$ in striatum (Figure 2). In hippocampus, the respective $\mathrm{pIC}_{50} \mathrm{~s}$ were $7.56 \pm 0.08,7.52 \pm 0.06$, and $7.68 \pm 0.05$ in SHRs, LEW, and WKY rats. By means of the Cheng-Prusoff equation $\left[\mathrm{K}_{\mathrm{i}}=\mathrm{IC}_{50} /\left(1+\mathrm{C} / \mathrm{K}_{\mathrm{m}}\right)\right]$ (Cheng and Prusoff 1973), the following $\mathrm{K}_{\mathrm{i}} \mathrm{s}$ were calculated: $23.81 \pm 2.4$, $25.39 \pm 3.66$, and $17.62 \pm 0.77 \mathrm{nM}$ in SHRs, LEW, and WKY rats, respectively. In striatum, the respective $\mathrm{pIC}_{50}$ s were $7.70 \pm 0.18,7.64 \pm 0.07$, and $7.67 \pm 0.12$ in SHRs, LEW, and WKY rats, with respective $\mathrm{K}_{\mathrm{i}} \mathrm{s}$ of: $17.13 \pm$ $3.5,18.87 \pm 2.3$, and $19 \pm 2.2 \mathrm{nM}$.

Neither in hippocampal nor in striatal synaptosomes did the ANOVAs reveal a significant strain effect on $\mathrm{K}_{\mathrm{i}}$; actually, such a lack of a genetic influence extended to the basal level (i.e., without citalopram) of $10 \mathrm{nM}\left[{ }^{3} \mathrm{H}\right] 5-$ HT reuptake on hippocampal and striatal synaptosomes, thus confirming above mentioned data.

\section{In Vivo Effects of Citalopram $(1 \mu \mathrm{M})$ on Hippocampal Extracellular Levels of 5-HT}

To determine whether the lack of a strain-dependent difference in the in vitro SSRI effect of citalopram applied to in vivo conditions, we then examined, by means of intrahippocampal microdialysis, the influence of a local citalopram perfusion on extracellular 5-HT levels. When extracellular 5-HT concentrations (i.e., absolute values in fmoles) were first taken in consideration, it was found that baseline levels, as assessed through the 
Table 3. Membrane $\left[{ }^{3} \mathrm{H}\right]$ citalopram Binding and Synaptosomal $\left[{ }^{3} \mathrm{H}\right]$ 5-HT Reuptake in the Hippocampus and Striatum of SHR, LEW, and WKY Rats

\begin{tabular}{|c|c|c|c|c|c|}
\hline & \multicolumn{3}{|c|}{$\left[{ }^{3} \mathrm{H}\right]$ citalopram binding } & \multicolumn{2}{|c|}{$\left[{ }^{3} \mathrm{H}\right] 5-\mathrm{HT}$ reuptake } \\
\hline & $2 \mathrm{nM}$ & (fmol/mg protein) & $10 \mathrm{nM}$ & $\mathrm{V}_{\max }(\mathrm{pmol} / \mathrm{min} / \mathrm{mg}$ protein $)$ & $\mathrm{K}_{\mathrm{m}}(\mathrm{nM})$ \\
\hline \multicolumn{6}{|c|}{ Hippocampus } \\
\hline SHR & $138 \pm 17$ & & $264 \pm 36$ & $1.89 \pm 0.16$ & $58.3 \pm 10.5$ \\
\hline LEW & $130 \pm 28$ & & $202 \pm 29$ & $2.17 \pm 0.30$ & $56.3 \pm 7.1$ \\
\hline WKY & $90 \pm 15$ & & $154 \pm 20^{a}$ & $1.88 \pm 0.09$ & $53.9 \pm 7.3$ \\
\hline \multicolumn{6}{|c|}{ Striatum } \\
\hline SHR & $294 \pm 37$ & & $430 \pm 44$ & $3.88 \pm 0.30$ & $86.5 \pm 13.0$ \\
\hline LEW & $334 \pm 35$ & & $514 \pm 54$ & $2.80 \pm 0.31$ & $52.3 \pm 5.4$ \\
\hline WKY & $313 \pm 30$ & & $484 \pm 48$ & $3.71 \pm 0.33$ & $74.8 \pm 11.5$ \\
\hline
\end{tabular}

$\left[{ }^{3} \mathrm{H}\right]$ citalopram binding was performed with two different concentrations $(2 \mathrm{nM}$ and $10 \mathrm{nM})$, whereas $\left[{ }^{3} \mathrm{H}\right] 5$-HT reuptake was performed with 5 concentrations of $\left[{ }^{3} \mathrm{H}\right]$ 5-HT ranging from 10 to $200 \mathrm{nM}$. Data are the mean \pm SEM of $6-8$ assays $\left(\left[{ }^{3} \mathrm{H}\right]\right.$ citalopram binding) or $4-5$ assays $\left(\left[{ }^{3} \mathrm{H}\right] 5-\mathrm{HT}\right.$ reuptake).

${ }^{a} p<.01$ for the difference between SHRs and WKY rats. Post hoc comparisons for $\mathrm{K}_{\mathrm{m}}$ and $\mathrm{V}_{\max }$ values are not given due to lack of significant ANOVAs (see text).

first $2 \mathrm{~h}$ of collection, were different between strains $(\mathrm{F}(2,10)=8.0, p=.0083)$. Thus, these levels were higher in LEW rats $(19.4 \pm 6.5 \mathrm{fmol} / 20 \mathrm{~min})$ than in SHRs $(5.3 \pm 1.5 \mathrm{fmol} / 20 \mathrm{~min}, p<.01)$ and WKY rats $(5.5 \pm 1.5$ fmol $/ 20$ min, $p<.01)$.
In keeping with such a difference, the respective 2-h effects of citalopram and Ringer perfusion on extracellular 5-HT levels were analysed as percent increases from baseline levels (first $2 \mathrm{~h}$ of collection). As shown in Figure 3, collection time had a significant influence in
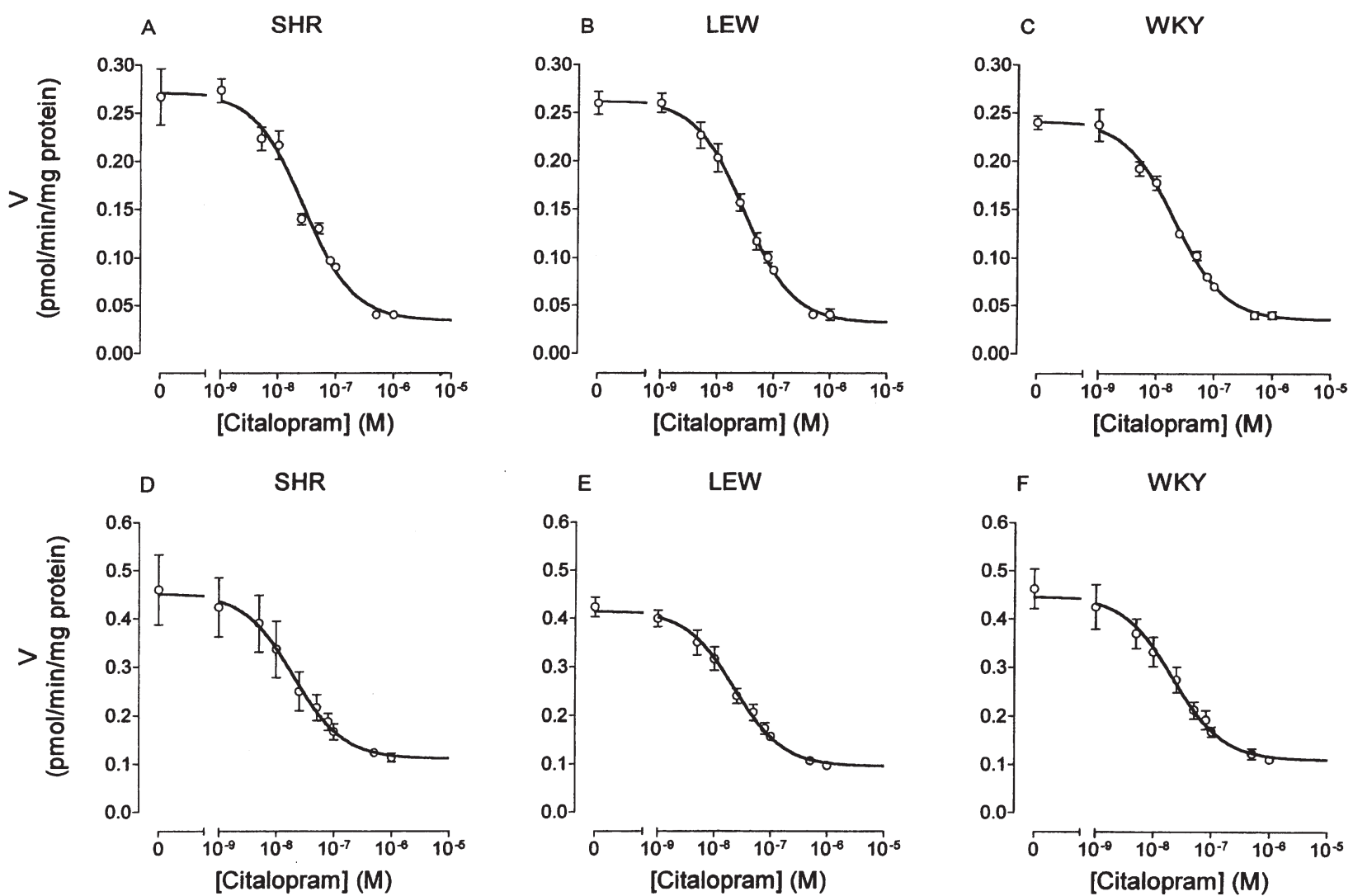

Figure 2. In vitro effects of citalopram (1-1000 nM) on $10 \mathrm{nM}\left[{ }^{3} \mathrm{H}\right] 5-\mathrm{HT}$ reuptake into hippocampal synaptosomes from SHRs (A), LEW (B), and WKY rats (C) and striatal synaptosomes from SHRs (D), LEW (E), and WKY rats (F). Each value is the mean \pm SEM of three assays. The $\mathrm{K}_{\mathrm{i}}$ was found to be respectively $23.81 \pm 2.4,25.39 \pm 3.66$, and $17.62 \pm 0.77 \mathrm{nM}(\mathrm{A}, \mathrm{B}$, and $\mathrm{C}$, respectively), and $17.13 \pm 3.5,18.87 \pm 2.3$, and $19 \pm 2.2 \mathrm{nM}(\mathrm{D}, \mathrm{E}$, and $\mathrm{F}$, respectively). 

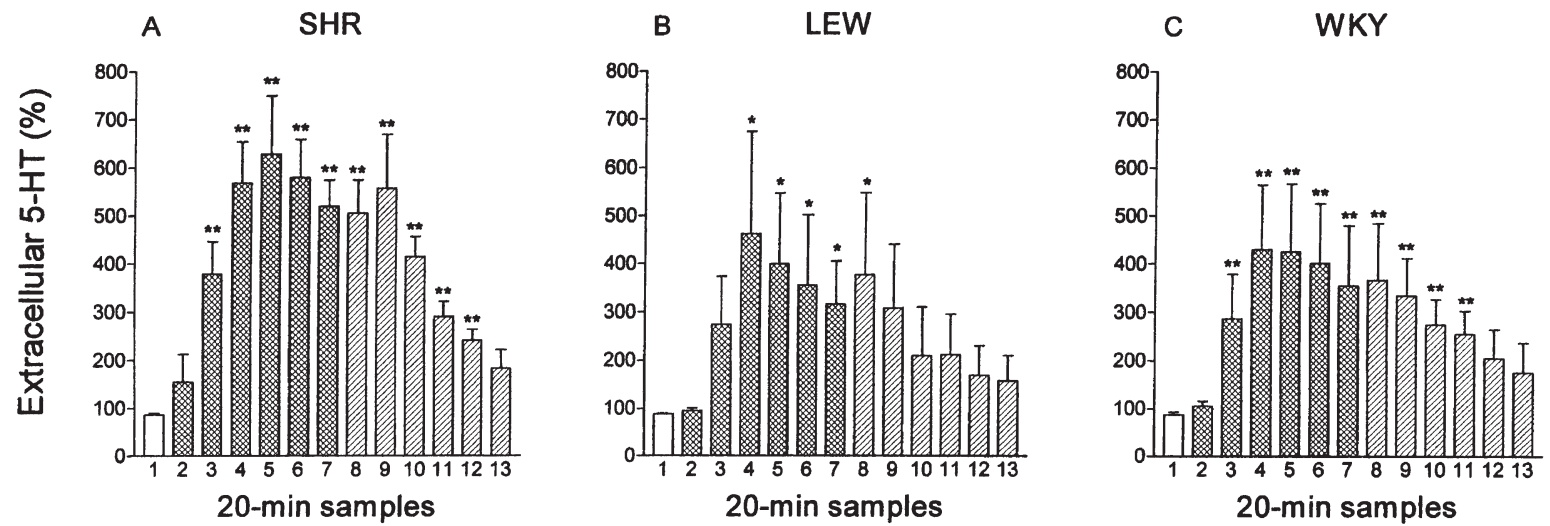

Figure 3. Effects of 2-h perfusions with a modified Ringer's solution (referred to as basal), a $1 \mu \mathrm{M}$ citalopram solution, and again a modified Ringer's solution (referred to as Ringer) on extracellular 5-HT levels in the ventral hippocampus of SHRs (A), LEW (B), and WKY rats (C). Data are expressed as percentages of the baseline value, which is the mean of 6 consecutive samples (for the sake of clarity, only the last of these samples, referred to as $\mathrm{N}^{0} 1$, is shown). All data are the mean \pm SEM of $4-5$ rats/strain. ${ }^{*} p<.05$ and ${ }^{* *} p<.01$ for the respective differences with sample $\mathrm{N}^{\mathrm{*}} 1$ in each strain.

all strains $(\mathrm{F}(12,48)=14.4, \mathrm{~F}(12,36)=4.7$, and $\mathrm{F}(12,36)=$ 8.8 in SHRs, LEW, and WKY rats, respectively, at least $p<.001]$, with citalopram increasing significantly relative extracellular 5-HT levels in all rats (Figure 3).

Although citalopram-elicited increases in extracellular 5-HT tended to be higher in SHRs, as compared to the other strains, neither the strain factor nor the strain $\times$ time interaction had significant influences. Confirmingly, the respective areas under the curves during citalopram perfusion were not significantly different between strains (data not shown). Of note is the observation that the maximal increases in extracellular 5 -HT levels $(628 \pm 121 \%, 461 \pm 213 \%$, and $429 \pm 135 \%$ in SHRs, LEW, and WKY rats, respectively; Figure 3), which were observed 60-80 min after the onset of citalopram, showed high variability in LEW rats. When expressed as absolute values $(35.6 \pm 8.3,58.8 \pm 9.1$, and $20.8 \pm 4.3$

Table 4. Effects of Citalopram on Hippocampal $\left[{ }^{3} \mathrm{H}\right]$ 5-HT Uptake in SHR and WKY Rats

\begin{tabular}{lcc}
\hline & \multicolumn{2}{c}{ Citalopram (mg/kg, i.p.) } \\
\cline { 2 - 3 } & \multicolumn{1}{c}{$\mathbf{0}$} & \multicolumn{1}{c}{3.3} \\
\hline $\mathrm{V}_{\max }(\mathrm{pmol} / \mathrm{min} / \mathrm{mg}$ protein) & & \\
SHR & $2.10 \pm 0.11$ & $2.64 \pm 0.06$ \\
WKY & $1.91 \pm 0.19$ & $2.22 \pm 0.31$ \\
$\mathrm{~K}_{\mathrm{m}}(\mathrm{nM})$ & & \\
SHR & $83.1 \pm 10.9$ & $167.3 \pm 9.9^{a}$ \\
WKY & $83.3 \pm 15.4$ & $157.3 \pm 36.9^{a}$
\end{tabular}

The animals were treated with $0.9 \% \mathrm{NaCl}$ or citalopram $1 \mathrm{~h}$ before sacrifice. Data are the mean \pm SEM values of 4 rats/treatment/strain.

${ }^{a} p<.05$ compared with $0.9 \% \mathrm{NaCl}$ (citalopram 0 ).

Note that citalopram-elicited increases in $\mathrm{K}_{\mathrm{m}}$ values were strain-independent. $\mathrm{fmol} / 20 \mathrm{~min}$ in SHRs, LEW, and WKY rats, respectively), the maximal increases in extracellular 5-HT levels were found to differ only between LEW and WKY rats $(p<.01)$, in agreement with the high baseline levels observed in LEW rats, compared with SHRs and WKY rats (see above). Lastly, citalopram effects on dialysate 5-HT were reversible, as the replacement of citalopram by Ringer's solution allowed extracellular 5-HT levels to return progressively toward baseline levels in all strains (Figure 3).

\section{Ex Vivo Effects of Citalopram $(3.3 \mathrm{mg} / \mathrm{kg}, 1 \mathrm{~h}$ beforehand) on $\left[{ }^{3} \mathrm{H}\right] 5-\mathrm{HT}$ Reuptake (10-200 nM) into Hippocampal Synaptosomes}

These experiments were aimed at detecting putative SHR/WKY differences in the ability of systemically administered citalopram to inhibit 5-HT reuptake. As shown in Table 4, citalopram pretreatment increased in a strain-independent manner $\mathrm{V}_{\max }(\mathrm{F}(1,12)=4.9, p=$ $.046)$ and $\mathrm{K}_{\mathrm{m}}(\mathrm{F}(1,12)=13.8, p=.003)$ values, with the respective increases in $K_{m}$ values $(89-101 \%)$ being predominant over $\mathrm{V}_{\max }$ increases (17-26\%), as expected for competitive inhibition.

\section{DISCUSSION}

\section{Strain-Related Differences in the Behavioural Effects of Citalopram}

On acute administration to rodents, SSRIs display anxiogenic (Chopin and Briley 1987; Handley and McBlane 1993; Griebel et al. 1994), anxiolytic (Jackson et al. 1995; Sanchez 1995; Schreiber et al. 1998), or no effects at all 
(Lightowler et al. 1994) depending on the dose and the anxiety model used. With regard to the rat elevated plusmaze test, principal component analyses have indicated that anxiety is inversely correlated with the percentages of the number of visits to, and time spent on, the open arms, the latter variable being actually the most indicative (File 1991; Cruz et al. 1994; Ramos et al. 1997). On the other hand, closed arm entries are related to locomotor reactivity, whereas the total (open and closed) number of arms visited is affected both by anxiety and locomotor reactivity levels (File 1991; Cruz et al. 1994; Ramos et al. 1997).

In the present study, citalopram pretreatment reduced the percent time spent on open arms by SHRs whereas in the two other strains, baseline levels of open arm behaviours were so low (thus confirming that these strains are highly anxious, compared with SHRs) that the anxiogenic effects of citalopram, if any, could not be detected.

The number of closed arm entries was reduced by citalopram in a dose-dependent manner in SHRs and LEW rats, but not in WKY rats. In SHRs, it is noteworthy that citalopram elicited its maximal anxiogenic effect at a dose $(1 \mathrm{mg} / \mathrm{kg})$ which did not affect locomotion, thereby indicating that citalopram-elicited anxiety and hypolocomotion are two independent behavioural dimensions. As far as WKY rats are concerned, the present experiments confirm that this strain of rats displays low locomotion; however, contrarily to open arm behaviours, their numbers of closed, but also total, arm visits should have been sufficient enough to detect citalopram-elicited reductions in these numbers.

It remains to know whether such a lack of effect of citalopram on the number of closed and total arms visited by WKY rats is drug-specific or extends to other hypolocomotor drugs. It this context, it is noteworthy that on acute, but not repeated administration, WKY rats are resistant to the anti-immobility effect of the nonselective 5-HT reuptake inhibitor, imipramine, in the forced swim test (Lahmame et al. 1997). In the latter case, serotonergic, but also noradrenergic systems may be involved as WKY rats (and SHRs) are resistant to the antiimmobility effect of the noradrenaline reuptake inhibitor desipramine (Lahmame and Armario 1996). In the present study, the possibility that the resistance of WKY rats to citalopram-elicited hypolocomotion involves the failure of the drug to reach serotonergic neurones and/ or to inhibit 5-HT reuptake was then examined.

\section{Strain-Related Differences in the Effects of Citalopram on Central 5-HT and 5-HIAA Levels}

Pretreatment with 1-10 mg/kg citalopram, i.e., doses that increase extracellular 5-HT levels in different brain regions with maximal effects, $1 \mathrm{~h}$ after systemic administration (for example, Invernizzi et al. 1992; Hjorth 1993), increased in a dose-dependent manner midbrain 5-HT levels in all strains, either to significant (SHRs and
WKY rats) or to non significant (LEW rats) extents. In addition, the reductions in 5-HIAA levels were already maximal with the lowest dose of citalopram in SHRs (as revealed by the lack of statistical difference between citalopram-treated groups), an observation that could be extended to hippocampal 5-HIAA levels. In striatum, however, it was observed that the WKY rat strain was that which displayed the highest sensitivity to the inhibitory effects of citalopram on 5-HT metabolism.

Taken together, all these data indicated that WKY rats were actually sensitive to the inhibitory effects of citalopram on 5-HT metabolism, as opposed to the behavioural effects of the SSRI. Such an observation yet allowed us to reject the above mentioned hypothesis that citalopram did not reach its direct serotonergic targets in WKY rats. It is noteworthy, however, that tissue 5-HT and 5-HIAA measurements were conducted in rats submitted to a 5-min elevated plus-maze test; because such a paradigm may affect both reuptake and release processes (File et al. 1993), the possibility that the amplitude of citalopram-elicited changes in tissue 5-HT and 5-HIAA levels would be different in naive animals is to be considered.

In keeping with our knowledge on the mechanisms through which SSRIs reduce 5-HIAA levels on acute administration, genetic differences in the direct (5-HT reuptake) and indirect (nerve firing, 5-HT autoreceptors, 5-HT turnover and metabolism) targets of citalopram may underlie the above mentioned results. Indeed, the 5-HT transporter and reuptake data presented below do not support the hypothesis of genetic differences in that target. On the other hand, data related to genetic differences with regard to the indirect targets of citalopram are either lacking (nerve firing) or scarce (5-HT autoreceptors, 5-HT turnover/metabolism).

As far as 5-HT autoreceptors are concerned, SHRs display a higher number of medullary $\left[{ }^{3} \mathrm{H}\right] 8$-hydroxy-2-(di$\mathrm{N}$-propylamino)tetralin binding sites than WKY rats (Huguet and Brisac 1991). However, it is unknown whether such a strain-related difference in $5-\mathrm{HT}_{1 \mathrm{~A}}$ autoreceptor numbers in the medulla is functional, and if so, whether it extends to the MRN. Beside, midbrain 5- $\mathrm{HT}_{1 \mathrm{~A}}$ autoreceptor number and midbrain $5-\mathrm{HT}_{1 \mathrm{~A}}$ autoreceptor-mediated inhibition of 5-HT turnover were reported to be equivalent between SHRs and LEW rats (Kulikov et al. 1997).

Data regarding putative strain-related differences in other 5-HT autoreceptors $\left(5-\mathrm{HT}_{1 \mathrm{~B}}, 5-\mathrm{HT}_{1 \mathrm{D}}\right)$ are scarce too. One study, aimed at comparing SHRs and WKY rats of three different ages, reported that neither the strain nor the age of the rats affected the evoked release of $\left[{ }^{3} \mathrm{H}\right] 5-\mathrm{HT}$ in cortex or the respective inhibitory and facilitatory effects of 5-HT and methiotepin on the latter variable, whether examined in slices or synaptosomes (Schlicker et al. 1988). Finally, some reports have indicated that 5-HT turnover, 5-HT levels, and 5-HIAA levels were all increased in lower midbrain nuclei of 4-, but 
not 14-week old SHRs, compared with age-matched WKY rats, with the former strain difference vanishing when the DRN was examined (Koulu et al. 1986a, b).

\section{Strain-Related Differences in 5-HT Transporters and 5-HT Reuptake}

By means of $\left[{ }^{3} \mathrm{H}\right]$ citalopram binding at 5 - $\mathrm{HT}$ transporters, we have previously reported that the number of hippocampal, but not midbrain, 5-HT transporters was higher in SHRs than in WKY rats (Durand et al. 1999). On the other hand, neither in midbrain nor in hippocampus did SHRs differ from LEW rats (Kulikov et al. 1997). The present study confirms these results and extends our knowledge to striatal 5-HT transporters, the number of which did not significantly vary among strains. Besides the observation that the rank order in the regional densities of 5-HT transporters (midbrain $>$ striatum $>$ hippocampus) is in agreement with past data (D'Amato et al. 1987; Hrdina et al. 1990), our analyses of midbrain 5-HT transporters contradict the report according to which 5-HT transporter number, as assessed by means of $\left[{ }^{3} \mathrm{H}\right]$ paroxetine binding, is higher in WKY rats than in SHRs (Gulati et al. 1993). Protocol differences (ligand, substrains) could underlie such a discrepancy. Lastly, the observation that only in hippocampus did WKY rats display decreased $\left[{ }^{3} \mathrm{H}\right]$ citalopram binding, compared with SHRs, already suggested a strain-dependent involvement of local posttranscriptional factors (Blakely et al. 1997, 1998) rather than genetic differences in the expression of the 5-HT transporter gene.

With regard to the difference in hippocampal $\left[{ }^{3} \mathrm{H}\right] \mathrm{cit}-$ alopram binding between SHRs and WKY rats (and which warrant further studies by means of saturation experiments), we then examined whether this difference was functional or not, as assessed by means of synaptosomal 5-HT reuptake. As an internal control, striatal synaptosomes were also assayed in that study. It was found that the strains did not differ with respect to $\mathrm{V}_{\max }$ and $\mathrm{K}_{\mathrm{m}}$ values of hippocampal $\left[{ }^{3} \mathrm{H}\right] 5-\mathrm{HT}$ reuptake. Taken with hippocampal $\left[{ }^{3} \mathrm{H}\right]$ citalopram binding data, this lack of a strain difference in $\left[{ }^{3} \mathrm{H}\right] 5$-HT reuptake underlines the key functional role of posttranslational regulators, as strikingly emphasized in mice bred from 5-HT transporter-deficient mice and control mice. Thus, although in homozygous 5-HT transporter-deficient mice, cerebral 5-HT transporter binding and 5-HT reuptake are absent, in heterozygous mice, the expected $50 \%$ reduction in 5-HT transporter binding was associated with a $100 \%$ efficient 5 -HT reuptake (Bengel et al. 1998).

\section{5-HT Reuptake Inhibitory Properties of Citalopram in the Three Strains}

In vitro, it was found that citalopram exerted its 5-HT reuptake inhibitory property with similar potency in the three strains. Although such an in vitro potency (17$25 \mathrm{nM})$ was almost similar to that reported in cortical synaptosomes $\left(\mathrm{K}_{\mathrm{i}}=11.2 \mathrm{nM}\right)$ (Wong et al. 1991), it was one range lower than that reported using whole brain $\left(\mathrm{K}_{\mathrm{i}}=1.5 \mathrm{nM}\right)\left(\right.$ Hyttel 1982) or hypothalamus $\left(\mathrm{K}_{\mathrm{i}}=2.6 \mathrm{nM}\right)$ (Thomas et al. 1987) synaptosomes, a difference that is likely to be accounted for by strain, region and/or $\left[{ }^{3} \mathrm{H}\right] 5-\mathrm{HT}$ reuptake preparation differences. Of note was the observation that $1 \mu \mathrm{M}$ citalopram did not fully block $\left[{ }^{3} \mathrm{H}\right] 5-\mathrm{HT}$ reuptake in hippocampus or striatum. Actually, the observation that as much as $12-16 \%$ (hippocampus) or $23-25 \%$ (striatum) of $\left[{ }^{3} \mathrm{H}\right] 5-\mathrm{HT}$ reuptake was resistant to citalopram could be linked to previous ones, obtained by means of chronoamperometry and microdialysis, and which indicated that a significant amount of hippocampal and striatal 5-HT may respectively undergo reuptake by noradrenergic (Daws et al. 1998) and dopaminergic (De Deurwaerdère et al. 1996) transporters, targets for which citalopram shows weak affinity $\left(\mathrm{K}_{\mathrm{i}}=5.75\right.$ and $36.61 \mu \mathrm{M}$, respectively) (Hyttel 1982). Whatever the nature of that citalopram-resistant portion, our results show that the three rat strains differed neither with respect to the SSRI property of citalopram (as indicated by the respective $\mathrm{K}_{\mathrm{i}} \mathrm{s}$ ) nor with respect to that citalopram-resistant portion (as indicated by the respective lower plateau levels).

The suggestion, based on in vitro data, that the SSRI potency of citalopram is similar between strains, especially between SHRs and WKY rats, was apparently reinforced by microdialysis and ex vivo experiments in the hippocampus. The continuous monitoring of extracellular 5-HT levels in the ventral hippocampus of conscious rats revealed reversible citalopram-induced increases in dialysate 5-HT in all strains, their amplitudes being similar to those observed in the hippocampus of other rat strains (Sharp et al. 1989; Invernizzi et al. 1995). In fact, these intrinsic increases, as assessed by the percent rises from baseline levels, did not vary significantly between strains although in SHRs dialysate 5-HT levels tended to rise sooner and to a higher extent during $1 \mu \mathrm{M}$ citalopram perfusion.

On the other hand, it was found that strains differed significantly with respect to baseline 5-HT levels, with LEW rats displaying much higher levels than the other strains. Indeed, a review of all the data available so far in other strains such as the Wistar or the Sprague-Dawley rat strains indicates that baseline hippocampal levels of 5-HT approximate $2-5 \mathrm{fmol} / 20 \mu \mathrm{l}$. In turn, this observation indicates that the present strain-dependent differences in baseline 5-HT levels may be accounted for by high levels in LEW rats rather than low levels in the other two strains.

Previous data obtained either in rats lesioned with the serotonergic neurotoxin 5,7-dihydroxytryptamine or in rat strains differing for their rates of 5-HT uptake have indicated that baseline extracellular 5-HT levels are independent from rates of 5-HT uptake and/or tis- 
sue 5-HT levels (Romero et al. 1998). This was also true in the present study as the high baseline extracellular 5 -HT levels in the hippocampus of LEW rats could not be explained by genetic differences in tissue 5-HT or $\left[{ }^{3} \mathrm{H}\right] 5-\mathrm{HT}$ reuptake. Because baseline extracellular 5-HT levels depend also on the firing rate of serotonergic neurons (and then release of the amine) and neuronal and glial monoamine oxidase activities, either mechanism could be responsible for such a characteristic of LEW rats. However, as 5-HT reuptake inhibition by 1 $\mu \mathrm{M}$ citalopram in LEW rats promoted the largest increments in absolute, but not in relative (percent changes) 5 -HT levels, any explanation based on differences in release rate and/or monoamine oxidase activities is rendered unlikely. This paradoxical finding may thus be accounted for by either subtle, albeit undetectable, genetic differences in innervation, firing and release rate, reuptake and/or monoamine oxidase activities (the sum of which leads to the aforementioned results) or by the experimental setting (local inflammatory processes and/or incomplete recovery from surgery in LEW rats).

The first explanation may also hold true for the net effect of citalopram in SHRs: when compared with WKY rats, both absolute and relative citalopram-elicited increases in extracellular 5-HT tended to be higher in SHRs, although neither baseline levels of 5-HT, nor the in vitro and ex vivo (see below) SSRI properties of citalopram, differed between these two strains. On the other hand, microdialysis data would fit with the interstrain difference in hippocampal $[3 \mathrm{H}]$ citalopram binding (SHR > WKY rat), thus raising the crucial question of the respective physiological relevance of protein binding assays on the one hand, and synaptosomal 5-HT reuptake assays on the other hand.

Lastly, the ex vivo effect of systemically administered citalopram on hippocampal $\left[{ }^{3} \mathrm{H}\right] 5-\mathrm{HT}$ reuptake was assessed in the two strains showing the most divergent behavioural and neurochemical responses to the SSRI, namely SHRs and WKY rats. Our ex vivo results do strongly suggest that citalopram is equipotent in WKY rats and SHRs, indicating a lack of genetic variability in drug concentrations reaching their target on systemic administration.

\section{Do Strain-Related Differences in the Behavioural Responses to Citalopram Involve Pre- and/or Postsynaptic Mechanisms?}

Taken together, the aforementioned in vitro, in vivo and ex vivo experiments indicate that the behavioural insensitivity of WKY rats to citalopram does not depend on the primary effect of the drug, i.e., 5-HT reuptake inhibition. Thus, compared with the strain displaying the highest behavioural sensitivity to citalopram, namely SHRs, WKY rats either did not differ (in vitro and ex vivo synaptosomal preparations) or differed slightly (in vivo microdialysis) with respect to the SSRI property of citalopram. In the latter case (microdialysis), the results suggest that although a genetic difference in 5-HT transporters could play a role, this is likely to be of minor importance, as revealed by the inter-strain comparison of citalopram-elicited increases in extracellular 5-HT levels.

In keeping with the behavioural observations, all these results favor the hypothesis of a genetic difference in the indirect (i.e., secondary to reuptake blockade) stimulation of postsynaptic receptors by citalopram. This could involve differences in 5-HT release and/or sensitivity of postsynaptic receptors, at least those that mediate citalopram indirect effects on anxiety and locomotor reactivity. In keeping with the great number of serotonergic receptors that are known to modulate anxiety- and activity-related behaviours (Griebel 1995), any suggestion as to the identity of the receptor(s) involved therein is premature.

\section{ACKNOWLEDGMENTS}

The authors wish to thank Dr. M. Hamon, Dr. M.-P. Martres (both at INSERM U288, Paris, France), and Dr. B. Assié (Laboratoires Pierre Fabre, Castres, France) for their advices regarding $\left[{ }^{3} \mathrm{H}\right] 5-\mathrm{HT}$ reuptake assays; Dr. Sandra Hogg $(\mathrm{H}$. Lundbeck A/S, Valby, Denmark) for revising the manuscript; as well as E. Bouix and A.-S. Perdrizet (Bordeaux), R. Berckmans, G. De Smet, R.-M. Geens, and C. de Rijck (Brussels) for their excellent technical assistance.

\section{REFERENCES}

Amara SG, Kuhar MJ (1993): Neurotransmitter transporters: Recent progress. Ann Rev Neurosci 16:73-93

Bengel D, Murphy DL, Andrews AM, Wichems CH, Feltner D, Heils A, Mössner R, Westphal H, Lesch K-P (1998): Altered brain serotonin homeostasis and locomotor insensitivity to 3,4-methylenedioxymethamphetamine ("Ecstasy") in serotonin transporter-deficient mice. Mol Pharmacol 53:649-655

Blakely RD, Ramamoorthy S, Qian Y, Schroeter S, Bradley C (1997): Regulation of antidepressant-sensitive serotonin transporters. In Reith MEA (ed), Neurotransmitter Transporters: Structure, Function, and Regulation. Totowa, NJ, Humana Press, pp 29-72

Blakely RD, Ramamoorthy S, Schroeter S, Qian Y, Apparsundaram S, Galli A, DeFelice LJ (1998): Regulated phosphorylation and trafficking of antidepressant-sensitive serotonin transporter proteins. Biol Psychiatry 44:169-178

Bradford MM (1976): A rapid and sensitive method for the quantitation of microgram quantities of protein-dye binding. Anal Biochem 72:248-254

Cheng YC, Prusoff WH (1973): Relationship between the inhibition constant $\left(\mathrm{K}_{\mathrm{I}}\right)$ and the concentration of inhibitor which causes 50 per cent inhibition $\left(\mathrm{IC}_{50}\right)$ of an enzymatic reaction. Biochem Pharmacol 22:3099-3108 
Chopin P, Briley M (1987): Animal models of anxiety: the effect of compounds that modify 5-HT neurotransmission. Trends Pharmacol Sci 8:383-388

Collier DA, Arranz MJ, Sham P, Battersby S, Vallada H, Gill P, Aitchison KJ, Sodhi M, Roberts GW, Smith B, Morton J, Murray RM, Smith D, Kirov G (1996a): The serotonin transporter is a potential susceptibility factor for bipolar affective disorder. NeuroReport 7:1675-1679

Collier DA, Stöber G, Heils A, Catalano M, Di Bella D, Arranz MJ, Murray RM, Valada HP, Bengel D, Müller CR, Roberts GW, Smeraldi E, Kirov G, Sham P, Lesch K-P (1996b): A novel functional polymorphism within the promoter of the serotonin transporter gene: possible role in susceptibility to affective disorders. Mol Psychiatry 1:453-460

Cruz APM, Frei F, Graeff FG (1994): Ethopharmacological analysis of rat behavior on the elevated plus-maze. Pharmacol Biochem Behav 49:171-176

D'Amato RJ, Largent BL, Snowman AM, Snyder SH (1987): Selective labeling of serotonin uptake sites in rat brain by $\left[{ }^{3} \mathrm{H}\right]$ citalopram contrasted to labeling of multiple sites by $\left[{ }^{3} \mathrm{H}\right]$ imipramine. J Pharmacol Exp Ther 242:364-371

Daws LC, Toney GM, Gerhardt GA, Frazer A (1998): In vivo chronoamperometric measures of extracellular serotonin clearance in rat dorsal hippocampus: Contribution of serotonin and norepinephrine transporters. J Pharmacol Exp Ther 286:967-976

De Deurwaerdère $P$, Bonhomme $N$, Lucas G, Le Moal M, Spampinato U (1996): Serotonin enhances striatal dopamine outflow in vivo through dopamine uptake sites. J Neurochem 66:210-215

Durand M, Berton O, Aguerre S, Edno L, Combourieu I, Mormède $\mathrm{P}$, Chaouloff $\mathrm{F}$ (1999): Effects of repeated fluoxetine on anxiety-related behaviours, central serotonergic systems, and the corticotropic axis in SHR and WKY rats. Neuropharmacology 38:893-907

File SE (1991): The biological basis of anxiety. In Meltzer HY and Nerozzi D (eds), Current Practices and Future Developments in the Pharmacology of Mental Disorders. Amsterdam, The Netherlands, Elsevier, pp 159-165

File SE, Zangrossi H Jr, Andrews N (1993): Social interaction and elevated plus-maze tests: Changes in release and uptake of 5-HT and GABA. Neuropharmacology 32:217-221

Gentsch C, Lichsteiner M, Feer H (1987): Open field and elevated plus-maze: a behavioural comparison between Spontaneously Hypertensive and Wistar-Kyoto rats and the effects of chlordiazepoxide. Behav Brain Res 25:101107

Griebel G, Moreau JL, Jenck F, Misslin R, Martin JR (1994): Acute and chronic treatment with 5-HT reuptake inhibitors differentially modulate emotional responses in anxiety models in rodents. Psychopharmacology 113:463-470

Griebel G (1995): 5-HT interacting drugs in animal models of anxiety: more than thirty years of research. Pharmacol Ther 65:319-395

Gulati A, Arora RC, Crayton J (1993): Central serotonergic uptake mechanisms in hypertensive rats: Effects of clonidine and centhaquin. Eur J Pharmacol 231:151-156

Handley SL, McBlane JW (1993): 5HT drugs in animal models of anxiety. Psychopharmacology 112:13-20
Hjorth S (1993): Serotonin 5-HT $\mathrm{HA}_{1 \mathrm{~A}}$ autoreceptor blockade potentiates the ability of the 5-HT reuptake inhibitor citalopram to increase nerve terminal output of 5-HT in vivo: a microdialysis study. J Neurochem 60:776-779

Hrdina P, Foy B, Hepner A, Summers RJ (1990): Antidepressant binding sites in brain: Autoradiographic comparison of $\left[{ }^{3} \mathrm{H}\right]$ paroxetine and $\left[{ }^{3} \mathrm{H}\right]$ imipramine localization and relationship to serotonin transporter. J Pharmacol Exp Ther 252:410-418

Huguet F, Brisac AM (1991): Central 5- $\mathrm{HT}_{1 \mathrm{~A}}$-receptor binding in normotensive and spontaneously hypertensive rats. Fund Clin Pharmacol 5:259-262

Hyttel J (1982): Citalopram-pharmacological profile of a specific serotonin uptake inhibitor with antidepressant activity. Prog Neuro-Psychopharmacol Biol Psychiatry 6:277-295

Hyttel J (1994): Pharmacological characterization of selective serotonin ruptake inhibitors (SSRIs). Int Clin Psychopharmacol 9(Suppl 1):19-26

Invernizzi R, Belli S, Samanin R (1992): Citalopram's ability to increase the extracellular concentrations of serotonin in the dorsal raphe prevents the drug's effect in the frontal cortex. Brain Res 584:322-324

Invernizzi R, Bramante M, Samanin R (1995): Extracellular concentrations of serotonin in the dorsal hippocampus after acute and chronic treatment with citalopram. Brain Res 696:62-66

Jackson HC, Cheetham SC, Luscombe GP, Mazurkiewicz SE, Viggers JA, Heal DJ (1995): The anxiolytic effects of selective 5-HT reuptake inhibitors in the elevated plusmaze are not explained by reuptake inhibition or affinity for $5-\mathrm{HT}_{1 \mathrm{~A}, 2 \mathrm{~A}, 2 \mathrm{C}}$ and ${ }_{3}$ receptor subtypes. Br J Pharmacol 114:391P

Kendler KS (1996): Major depression and generalised anxiety disorder. Same genes, (partly) different environments-revisited. Br J Psychiatry 168:68-75

Kleyn PW, Vesell ES (1998): Genetic variation as a guide to drug development. Science 281:1820-1821

Koulu M, Saavedra JM, Bjelogrlic N, Niwa M, Agren H, Linnoila M (1986a): Serotonin turnover in discrete hypothalamic nuclei and mesencephalic raphe nuclei of young and adult spontaneously hypertensive rats. Brain Res 379:257-263

Koulu M, Saavedra JM, Niwa M, Scheinin M, Linnoila M (1986b): Association between increased serotonin metabolism in rat brainstem nuclei and development of spontaneous hypertension. Brain Res 371:177-181

Kulikov A, Aguerre S, Berton O, Ramos A, Mormède P, Chaouloff F (1997): Central serotonergic systems in the Spontaneously Hypertensive and Lewis rat strains that differ in the elevated plus-maze test of anxiety. J Pharmacol Exp Ther 222:775-784

Lahmame A, Armario A (1996): Differential responsiveness of inbred rat strains of rats to antidepressants in the forced swimming test: Are Wistar Kyoto rats an animal model of subsensitivity to antidepressants? Psychopharmacology 123:191-198

Lahmame A, Del Arco C, Pazos A, Yritia M, Armario A (1997): Are Wistar-Kyoto rats a genetic animal model of depression resistant to antidepressants? Eur J Pharmacol 337:115-123 
Lesch K-P, Bengel D, Heils A, Sabol SZ, Greenberg BD, Petri S, Benjamin J, Muller CR, Hamer DH, Murphy DL (1996): Association of anxiety-related traits with a polymorphism in the serotonin transporter transporter gene regulatory region. Science 274:1527-1531

Lightowler S, Kennett GA, Williamson IJR, Blackburn TP, Tulloch IF (1994): Anxiolytic-like effect of paroxetine in a rat social interaction test. Pharmacol Biochem Behav 49:281-285

Merikangas KR, Swendsen JD (1997): Genetic epidemiology of psychiatric disorders. Epidemiol Rev 19:144-155

Ogilvie AD, Battersby S, Bubb VJ, Fink G, Harmar AJ, Goodwin GM, Smith CAD (1996): Polymorphism in serotonin transporter gene associated with susceptibility to major depression. Lancet 347:731-733

Okamoto K, Aoki K (1963): Development of a strain of spontaneously hypertensive rats. Jpn Circ J 27:282-293

Paré WP (1989): Stress ulcer susceptibility and depression in Wistar Kyoto (WKY) rats. Physiol Behav 46:993-998

Paxinos G, Watson C (1986): The Rat Brain in Stereotaxic Coordinates, 2nd ed. New York, NY, Academic Press

Pellow S, Chopin P, File SE, Briley M (1985): Validation of open:closed arm entries in an elevated plus-maze as a measure of anxiety in the rat. J Neurosci Meth 14:149-167

Ramos A, Berton O, Mormède P, Chaouloff F (1997): A multiple test study of anxiety-related behaviours in six inbred rat strains. Behav Brain Res 85:57-69

Ramos A, Mellerin Y, Mormède P, Chaouloff F (1998): A genetic and multifactorial analysis of anxiety-related behaviours in Lewis and SHR intercrosses. Behav Brain Res 96:195-205

Romero L, Jernej B, Bel N, Cicin-Sain L, Cortes R, Artigas F (1998): Basal and stimulated extracellular serotonin concentration in the brain of rats with altered serotonin uptake. Synapse 28:313-321

Sanchez C (1995): Serotonergic mechansisms involved in the exploratory behaviour of mice in a fully automated twocompartment black and white test box. Pharmacol Toxicol 77:71-78
Schlicker E, Classen K, Göthert M (1988): Presynaptic serotonin receptors and alpha-adrenoceptors on central serotoninergic and noradrenergic neurons of normotensive and spontaneously hypertensive rats. J Cardiovasc Pharmacol 11:518-528

Schreiber R, Melon C, De Vry J (1998): The role of 5-HT receptor subtypes in the anxiolytic effects of selective serotonin reuptake inhibitors in the rat ultrasonic vocalization test. Psychopharmacology 135:383-391

Sharp T, Bramwell SR, Clark D, Grahame-Smith DG (1989): In vivo measurement of extracellular 5-hydroxytryptamine in hippocampus of the anaesthetized rat using microdialysis: Changes in relation to 5-hydroxytryptaminergic neuronal activity. J Neurochem 53:234-240

Smeraldi E, Zanardi R, Benedetti F, Di Bella D, Perez J, Catalano M (1998): Polymorphism within the promoter of the serotonin transporter gene and antidepressant efficacy of fluvoxamine. Mol Psychiatry 3:508-511

Thomas DR, Nelson DR, Johnson AM (1987): Biochemical effects of the antidepressant paroxetine, a specific 5-hydroxytryptamine uptake inhibitor. Psychopharmacology 93:193-200

Thorré K, Chaouloff F, Sarre S, Meeusen R, Ebinger G, Michotte Y (1997): Differential effects of restraint stress on hippocampal 5-HT metabolism and extracellular levels of 5-HT in streptozotocin-diabetic rats. Brain Res 772:209-216

Wichems CH, Sora I, Andrews AM, Bengel D, Uhl G, Lesch K-P, Murphy DL (1998): Altered responses to psychoactive drugs and spontaneous behavior differences in mice lacking the serotonin transporter. Fourth IUPHAR Satellite Meeting on Serotonin (Rotterdam, The Netherlands): Abst. OP3

Whitehorn D, Atwater DG, Low WC, Gellis JE, Hendley ED (1983): Independence of blood pressure and locomotor hyperactivity in normotensive and genetically hypertensive rats. Behav Neural Biol 37:357-361

Wong DT, Threlkeld PG, Robertson DW (1991): Affinities of fluoxetine, its enantiomers, and other inhibitors of serotonin uptake for subtypes of receptors. Neuropsychopharmacology 5:43-47 